\title{
MUSEUS: AGENTES DE INOVAÇÃO E TRANSFORMAÇÃO
}

Maria Ignez Mantovani Franco ${ }^{1}$

$\mathrm{Na}$ trajetória empreendida pelo ser humano desde seus primórdios até a contemporaneidade, vemos que há uma tríade de longo termo, que se enuncia e se articula.

Em artigo para a revista ouvirOUver, publicada pela Universidade Federal de Uberlândia, destaco que, "como primeiro elemento dessa tríade, registra-se a busca incessante pelo desconhecido, a busca do outro; o segundo, o domínio do território e o desenvolvimento dos artefatos de mediação com o mundo, ou seja, a conquista do conhecimento; e, por fim, a comunicação como estratégia de domínio e sobrevivência. Essa tríade, que foi angular para garantir a sobrevivência da espécie humana, ainda é válida atualmente" (FRANCO, 2017, p. 353).

Complemento que, com o passar do tempo, "tornou-se ainda mais necessário o entendimento das diferentes culturas como estratégia de compreensão dos processos de interação entre os povos. Entender a forma de pensar e agir de uma determinada sociedade passou a ser uma moeda de grande eficácia na percepção do novo, do desconhecido, enfim, do outro. Perceber como se desenvolvem as relações de poder, as formas de articulação, a construção de pensamentos, a formação histórica, os hábitos

\footnotetext{
${ }^{1}$ Museóloga, Diretora da Expomus, Ex-Presidente ICOM-Br, Phd em Museologia mi.icombra@gmail.com
} 
culturais, as estratégias de negociação tornou-se algo importante no diálogo ou nas disputas entre diferentes povos".

A cultura tem, portanto, o papel de elo de sentidos, de transposição, de entendimento e de comunicação entre distintos territórios e diferentes grupos humanos. Ela é capaz de atrair, engajar, encantar e, ao mesmo tempo, repudiar, rivalizar, excluir diferentes atores sociais, além de enunciar novas formas de expressão e de conquista.

Em conferência promovida pelo British Council e Museu do Amanhã (FRANCO, 2016), apresentei um vídeo inspiracional ${ }^{2}$ a partir do qual extraí as considerações que faço a seguir.

A ciência hoje coloca nossa história pessoal, familiar e coletiva num pequeno tubo de ensaio; os testes de DNA nos evidenciam que somos resultado de pontos híbridos, de múltiplas origens, muitas vezes distantes da fração do mundo em que habitamos.

O mapa-múndi deixou de ser autorreferente - ele pode hoje situar ancestralidades desconhecidas e até mesmo indesejadas para cada um de nós.

Seríamos nós, de alguma forma, parentes dos refugiados dos quais desviamos nosso olhar, dos quais evitamos nos aproximar, os quais buscamos ignorar?

${ }^{2}$ O vídeo em questão é uma ação da Momondo e é parte de uma campanha baseada em pesquisa global realizada pela AncestryDNA, com 7.200 pessoas que não tinham ideia da diversidade de suas origens. Em abril de 2016, 67 pessoas de todo o mundo foram convidadas para o projeto "The DNA Journey" em que, por meio de testes de DNA, poderiam descobrir mais sobre sua ascendência. $O$ resultado está neste vídeo, utilizado para o lançamento da campanha, produzido pela \& Co Agency e pela Bacon, em formato de um minidocumentário. Em parceria com dois laboratórios (AncestryDNA e 23andMe), a Momondo ampliou o projeto e lançou uma ação mundial que vai distribuir kits para que 500 pessoas de 19 países tenham a oportunidade de fazer o teste de DNA e gravar a reação ao receber o resultado do exame. Disponível em: https://youtu.be/tyaEQEmt5ls. Acesso em 30 set. 2018. 
Temos conseguido considerar a migração humana como um processo contínuo, uma grande permanência na trajetória humana?

Mais do que isso, a tecnologia e a ciência nos possibilitam descobrir não apenas para onde podemos ou devemos ir, mas também lugares inesperados de onde viemos que, de alguma forma, não sabíamos contemplados em nossa cadeia ancestral do DNA. Isso alterou nossos quadros referenciais de forma assustadora e revolveu, numa rapidez incrível, nossa capacidade de nos relacionar com a memória, com o sentido de pertencimento a nós mesmos, à nossa família, ao nosso país, ao nosso continente, ao nosso mundo e a novos mundos até agora desconhecidos, que podem se revelar e também vir a ser nossos.

Neste século em que vivemos, as questões intrínsecas de estabilidade das fronteiras políticas, econômicas, éticas, estéticas, étnicas já se esvaíram em prol de um plano de mutações crescentes.

Novas plataformas tecnológicas e comunicacionais transformam o hoje em amanhã, num piscar de olhos; elas possibilitam que possamos estar, presencial ou virtualmente, em qualquer ponto do mundo.

No entanto, uma ameaça terrorista nos impede de voar para um destino que prevíamos, um tremor de terra ou a erupção de um vulcão nos impede de curtir as férias tão esperadas, uma ameaça de pandemia nos impede de participar de um encontro internacional, ou seja, nossa vida é permeada de fatos imponderáveis, inevitáveis, que não podemos controlar. Os desastres ambientais, os recursos naturais finitos, as epidemias mundiais ou o terrorismo fazem de nós cidadãos do mundo ameaçados por sistemas de instabilidade global. Há situações que fogem ao controle do indivíduo e nos sentimos reféns de processos coletivos. Nascem daí novas formas de organização social, estruturadas sob a égide da mútua cooperação, experimentando novas redes compartilhadas de articulação.

E neste movimento de transformações aceleradas em que o mundo todo está envolto, o museu assume o papel social de 
ancoradouro da memória, de elo de pertencimento, de esteio das relações humanas, de entrelaçamento de expectativas, de interação entre as disciplinas, de construção de novas visões de mundo. Ao museu cabe rememorar a todos o que é importante lembrar e o que é preciso esquecer - ele nos apresenta novas leituras sobre o passado e nos evidencia ser fundamental salvaguardar o presente para nos referenciar no futuro.

O museu, lugar de interpretação e de construção de significados, ocupa uma posição privilegiada na cena contemporânea. Oferece um espaço e conteúdos de temporalidade amalgamada, reconstitui a memória do passado, testemunha e reflete sobre o presente, e constrói o patrimônio do amanhã.

Como criação humana, os museus não deveriam ficar submissos a uma replicação inalterável. É preciso fugir à tirania do DNA, ao determinismo genético. Verifica-se que um ser humano tem, em média, 60 mutações em relação aos seus pais, o que, no entanto, não se constitui em algo inesperado. O determinismo genético não pode ser negado, mas somos forçados a admitir que a replicação permite alguma "flutuação".

À semelhança do que ocorre com seus criadores, os seres humanos, os museus devem gerar seus "processos de mutação", no mínimo como forma de atender a um requisito de "seleção natural". Mutações podem, em alguns casos, proporcionar uma vantagem na luta pela vida, como parte desse processo de seleção natural. Assim, para se manterem vivos e atuantes na sociedade, os museus também devem assimilar as crises e as dissonâncias como elementos vitais de mutação social e institucional. Devem evoluir, mudar, transformar, reinventar a si próprios. Os casos em que os museus permanecem inertes e imunes às mudanças e transformações geram inexoravelmente processos perversos de estagnação. Não será difícil lembrar daqueles museus que, por não quererem ou não conseguirem se adaptar a novos tempos, pereceram.

Nada é mais complexo do que o cenário geopolítico que nos envolve e as consequentes distâncias ou interligações entre 
diferentes povos, culturas, entre diferentes religiões e formas de viver. Neste mundo permeado por tantas formas de extremismo, fundamentalismo, intolerância, dissidência, e muitas vezes de produtivas resistências, temos sim que nos perguntar sempre:

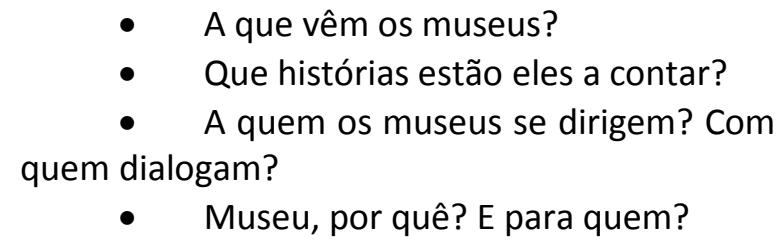

O museu é hoje um agente de transformação em rede, que se conecta de forma exponencial com outros elementos mutantes de múltiplas cadeias, todos voltados a cocriar novas relações, novas linguagens e tecnologias, propondo sinapses interativas e construtivas, capazes de transformar o presente e construir o futuro.

\section{A relevância das coleções no mundo dos museus}

Os museus contam, em sua essência, e a seu favor, com a relevância do objeto como fonte inesgotável de transmissão de histórias, atuando como espaço permanente de reconhecimento do mundo. Na contemporaneidade também nos valemos dos objetos para sintetizar histórias neste mundo híbrido e mutante, utilizando diferentes linguagens.

Ao museu cabe atuar na sensibilização de seus diferentes públicos, servindo-se de sua arma mais poderosa, ou seja, suas coleções, sejam elas históricas, artísticas, científicas, tecnológicas, entre outras. É a instituição vocacionada à construção do coletivo e à salvaguarda dos valores universais.

No contexto museológico, as coleções se compõem - ou se contrapõem - por meio de distintas associações, arregimentando diferentes discursos e leituras. 
Num espelhamento imediato, podemos dizer que a pluralidade das culturas e dos objetos que compõem o museu remetem à mesma representação da diversidade de origens e procedências que o teste de DNA pode revelar sobre o ser humano.

Falar em objetos e coleções nos remete, simbolicamente, a alguns pontos do pensamento de Neil MacGregor (2010), ex-diretor do British Museum, destacados no livro de sua autoria A History of the World in 100 Objects, que fundamentou uma série transmitida pela Rádio 4, da BBC, globalmente, em 2010. A seleção feita por especialistas do British Museum e de outras partes do mundo, sob a batuta de MacGregor, reuniu uma série de 100 objetos das coleções do museu, representativos de um período compreendido desde os primórdios da humanidade, há 2 milhões de anos, até a contemporaneidade. Os objetos escolhidos variaram de uma panela a um galeão dourado, de um utensilio da idade da pedra a um cartão de crédito, e representaram as mais diferentes culturas e temporalidades.

O primeiro ponto de reflexão trazido por MacGregor é a consciência de que, se quisermos contar a história do mundo, ela deve ser narrada pelos objetos, uma vez que apenas uma parte ínfima da história recente poderá ser contada por meio da escrita, já que ela é uma descoberta relativamente tardia na história humana (3 a 4 mil a.C.). Assim, vemos que os objetos assumem um papel estruturador nos museus e no mundo, como fontes inesgotáveis de narrativas coletivas que podem e devem ser compartilhadas socialmente.

Outra questão relevante apontada por MacGregor é o fato de que um único objeto tem o poder de contar distintas histórias, ou seja, ele perpassa períodos de ocupações, espólios de guerra, gabinetes de curiosidades, pode integrar diferentes e sucessivas coleções, agregando, a cada passagem, novos sentidos a ser interpretados pelos museus, e apropriados pelo público.

Por outro lado, o objeto, quando musealizado, está aberto a novas indagações e composições. Ou seja, está apartado do convívio social e continuamente disponível para ser analisado em novas 
pesquisas, e para compor novos conjuntos, novas séries, novos programas, novas exposições. É estimulante pensar que eles propiciam inesgotáveis oportunidades de livre associação, de leitura, de seleção, de justaposição, de questionamentos.

$\mathrm{Na}$ verdade, constatamos que, para contar distintas histórias do mundo, os museus conectam e inter-relacionam os objetos. Propõem, portanto, distintas formas de interlocução entre os objetos, com linguagens múltiplas, objetivos de comunicação distintos, capazes de provocar o público de forma a torná-lo um agente, um interlocutor, um artífice de múltiplas versões da história.

Assim como cada geração traz mutações genéticas e gera as diferenças entre si, o mesmo ocorre com a família dos objetos, ou seja, com as diferentes culturas. O encontro e a articulação entre essas múltiplas culturas se dá, no museu, por meio de objetos sagrados, rituais, bélicos, instrumentais, cotidianos, entre outros.

\section{A dimensão simbólica do museu}

Não por acaso, os museus serviram, historicamente, durante séculos, para sintetizar e reforçar discursos políticos, nacionalistas ou não, e salvaguardar, reafirmar os legados de estados hegemônicos. É dado ao museu o desafio contínuo de privilegiar diferentes narrativas, distintas histórias, contadas por objetos muitas vezes valiosos, insólitos ou inusitados, mas também por outros de feitura simples, de uso quotidiano, e de múltiplos significados, ligados prioritariamente ao território em que se situam e à comunidade que neles se representa.

O compromisso contemporâneo do museu é fazer com que a história da humanidade e de sua comunidade possa ser transmitida para o futuro, por meio dos objetos, sob a ótica do conhecimento humano. Olhar para o futuro significa acreditar que novas tecnologias e a ciência encontrarão novos signos, novos indícios e novas possibilidades de leitura dos mesmos objetos, propiciando 
um crescente conhecimento da história passada, presente e futura da humanidade.

Hoje conhecemos muito mais do passado do que quando ele era o presente; no futuro, conhecerão muito mais sobre nós e sobre o nosso presente, e certamente proporão novas releituras do nosso passado. O presente é um link entre o passado e o futuro, repleto de incertezas que não deixam de ser atemporais.

Devemos nos perguntar continuamente:

- Museus para quê?

- Para perpetuar a história da humanidade?

- Que outras histórias queremos ver repertoriadas: as nossas histórias regionais, locais, comunitárias, pessoais?

E que história da humanidade queremos ver perpetuada? Uma história também de vencidos e não apenas de vencedores? Quem terá melhores condições de contar a história de uns e de outros?

A história que queremos transmitir para o futuro depende de que natureza de museus desejamos construir e defender hoje; depende da camada de incertezas que pudermos suportar; depende essencialmente da nossa capacidade de conviver com a instabilidade, que é algo inerente ao nosso tempo.

Os museus podem ser espaços de reflexão, vocacionados a despertar a capacidade crítica, de percepção do outro, o valor do conhecimento e as múltiplas formas possíveis de convivência humana. São organizaçöes abertas à cocriação, à fruição compartilhada. 


\section{O museu polimorfo}

Um novo modelo de museu, que possa abarcar todas essas expectativas, é o museu polimorfo, como propõe Catherine Grenier (2013, pp. 79-83).

Considera-se que, historicamente, as principais funções atribuídas aos museus foram de ordem social, memorial, cultural e educativa.

Grenier propõe que o museu do futuro deve não apenas ser um conglomerado de novas funções e de novos públicos, mas ser uma construção unitária, onde a identidade e o jogo simbólico e social são solidários e claramente identificados.

Segundo a autora:

- O museu deve atuar de forma generalista, com grande potencial variado, que deve se abrir a novas missões e a públicos diversos. Ele deve mobilizar todos os seus recursos, em particular as suas coleções, numa dinâmica de projetos.

- Num contexto econômico adverso, somente uma dinâmica interna permitirá que o museu continue a inovar, estabelecer novas parcerias e adotar novas práticas colaborativas.

Grenier faz ainda uma analogia interessante, ao comparar o museu a um cérebro humano. Como em um cérebro, é sobre a multiplicidade e a renovação permanente das conexões que se fundamentam a capacidade de adaptação, a inteligência e a atratividade do museu. Polimorfo por natureza, o museu pode atuar de forma mais ampla em sua especialidade, e afirmar sua qualidade intrínseca. Baseado num princípio de dinâmica interna, o museu ativa o movimento das suas coleções, seus arquivos, seus fundos documentais, suas produções editoriais, sua história, seus espaços, enfim, sua "massa cinzenta". E ele trabalha inteiramente acionado por projetos. De naturezas diversas, os projetos podem ter uma dimensão histórica, crítica, estética, exploratória, filosófica, social, 
política. Ele se apoia nos recursos internos e externos que se ativam em diferentes lógicas e temporalidades.

O museu polimorfo é num determinado momento um museu reativo, um museu dinâmico que interage diretamente com o contexto imediato e com o mundo; é, ao mesmo tempo, um slow museum, "que interroga e realimenta de forma permanente os seus fundamentos. Esta reativação permanente dos seus princípios fundadores the permite evoluir sem perder a sua personalidade própria e sua legitimidade, em meio às múltiplas instituições existentes e a surgir". (GRENIER, p. 80) ${ }^{3}$

Em lugar da grande hierarquização, o museu deve retomar a prática do diálogo e da mobilidade, isso também no trato de suas coleções, na sua programação, na sua política de públicos e na participação na vida social.

A autora acrescenta que hoje, dada a complexidade das ações de um museu, ele deve atuar segundo os princípios da hibridação e da interatividade em todos os níveis e em todas as áreas do conhecimento.

A noção de pluridisciplinaridade deve evoluir para o princípio da mixagem disciplinar. À pluridisciplinaridade corresponde geralmente um mosaico de disciplinas que não convergem em sistemas transversais. Privilegiando colaborações transdisciplinares, o museu se afirmará como um lugar inovador e global.

E falando num dos temas transversais deste seminário, penso ser importante ressaltar que o trabalho transdisciplinar poderá sim ser um elemento energizante para o museu. Eu diria mesmo que, neste início de século, não precisamos de um museu acelerado, mas sim de um museu energético, capaz de manter o ritmo estável em um mundo vertiginoso, que consiga ser profundo e realizador num sistema absolutamente volátil, ou seja, que consiga energizar o mundo em que atua, trazendo à tona valores referenciais para uma determinada sociedade e seu contexto.

\footnotetext{
${ }^{3}$ Tradução nossa.
} 


\section{A polivalência dos museus}

Para se adaptar ao futuro, o museu não estará mais fechado em sua sede e seus escritórios. Nem nos limites físicos e temporais de sua coleção. Para se adaptar à evolução da sociedade, o museu deverá ser extensivo, flexível, penetrante, e aliar a sua função de continente àquela de realizador. Ele deverá reunir as funções de museu de arte ou de história, à de museu de civilização, procurando se dirigir aos públicos de cada um e de todos esses formatos de museu.

Polivalente, o museu se definirá como um museu mundo, um museu cidade, um museu campus, um museu fórum, um museu de território, um museu comunitário, um museu retrato, um museu think tank. ${ }^{4}$ Flexível, extensivo, o museu polimorfo de amanhã será um museu realizador e regenerador.

A polivalência dos museus deve estar também nas estratégias que possam garantir sua sustentabilidade. Hoje, mais do que nunca, com a escassez cada vez maior de recursos públicos para a cultura, para a ciência, para a educação - com raras exceções -, os museus grandes, médios e pequenos, tecnológicos ou não, são estimulados a buscar fontes alternativas de insumos para a própria sobrevivência. Além disso, os conceitos essenciais que definem museu de território e museu comunitário preconizam o comprometimento vital do museu com o desenvolvimento regional e local e com a melhoria da qualidade de vida dos habitantes de seu entorno, por meio do engajamento e articulação comunitários. Vemos, portanto, que o museu que conseguir valorizar a sua essência, o seu acervo, e tecer uma rede de articulação regional e

\footnotetext{
${ }^{4}$ Think tanks são organizações ou instituições que atuam no campo dos grupos de interesse, produzindo e difundindo conhecimento sobre assuntos estratégicos, com vistas a influenciar transformações sociais, políticas, econômicas ou científicas, sobretudo em assuntos sobre os quais pessoas comuns não encontram facilmente base para análise de forma objetiva. (In: MC CLATCHY, Steve. O poder da decisão: impacto no trabalho, redução do estresse, liderança inteligente. Trad.: Claudia Gerpe Duarte, Eduardo Gerpe Duarte. São Paulo: Cultrix, 2016.)
} 
local, terá maiores possibilidades de garantir a sustentabilidade da instituição e de seus programas.

No cenário de crescentes incertezas em que os museus operam contemporaneamente, há que se alterar a lógica antes baseada na solicitação de recursos financeiros, para a dinâmica de geração de fontes alternativas de sustentabilidade. Exemplos estimulantes têm sido elencados, mas o mais significativo é considerar que cabe a cada museu desenvolver suas estratégias próprias e definir suas fontes potenciais de cooperação, moldadas de acordo com as especificidades da região e da comunidade em que se insere.

Por ocasião da última Conferência Geral do Conselho Internacional de Museus - ICOM, realizada em julho de 2016, em Milão, em sua 24a edição, tivemos a oportunidade de assistir a uma mesa-redonda intitulada "O papel social dos museus: novas migrações, novos desafios", 5 que trouxe temas de grande relevância.

Um dos temas de interesse dessa mesa foi a caracterização, entre outras, do museu mundo, do museu fórum.

\section{Museu mundo}

- Não se trata de considerar um museu universal, que queira explicar o mundo, mas sim de um museu mundo, que conviva com as incertezas do momento contemporâneo, viva das diferenças entre os homens e seus diversos hábitos, crenças e formas de vida. Dentro de cada museu há um mundo e há também as especificidades culturais do contexto em que se encontra. Um museu mundo põe abaixo as

\footnotetext{
${ }^{5}$ Compuseram essa mesa: David Throsby, da Austrália, um dos nomes consagrados da economia da cultura; David Fleming, então diretor dos Museus Nacionais de Liverpool, Reino Unido; Giusi Nicolini, prefeita de Lampedusa, Itália; e Marlen Mouliou, da Grécia, então presidente do CAMOC - Comitê Internacional para as Coleções e Atividades de Museus de Cidades do ICOM.
} 
hierarquias entre países, estabelece a necessidade de uma solidariedade internacional em torno de temas relevantes para a vida humana; permite e propõe o compartilhamento de diferentes patrimônios e estabelece elos de conhecimento sobre eles.

- Ao museu mundo cabe compreender e dissolver impenetráveis formas de extremismo, de fundamentalismo, de intolerância, de autoritarismo, de xenofobia, de homofobia, de desrespeito, de exclusão, de desigualdade.

- O museu mundo não é o território da conformidade ou da neutralidade; o museu é sim o lugar da dissidência, da ruptura e da resistência. A ele cabe hibridar culturas, dirimir preconceitos, estreitar distâncias, reconhecer e respeitar diferenças.

- Num mundo marcado pela mutação, pelo terrorismo e pelo fundamentalismo, cada museu tem o seu papel de conectar sentidos e culturas capazes de compreender as diferenças e levar o indivíduo a conhecer, reconhecer e respeitar outras culturas que não a sua.

- Sem dúvida, no contexto mundial em que vivemos, os museus podem ser peças-chave para a harmonização social, espaços privilegiados para a compreensão do mundo. Esse museu solidário de que falamos deve apresentar uma modernidade multicultural e transcultural; deve se apropriar de diferentes conteúdos, diferentes linguagens, ser educador, ou seja, se caracterizar como um lócus de mediação por excelência.

- Os debates em torno dos temas polêmicos que agitam o mundo devem, sim, ter lugar no museu. 
- O museu passa a ser não apenas um lugar de descoberta, mas também de reflexão sobre o mundo.

\section{Museu fórum}

Mais do que se caracterizar como museu mundo, cabe ao museu assumir sua condição de museu fórum - o ágora ${ }^{6}$ - no sentido mais amplo da palavra grega.

O museu contemporâneo deve se caracterizar com esse espaço fórum, onde podemos cocriar as relações sociais, simulando constantemente o espaço e o tempo.

O museu fórum preconiza que a instituição se transforme num palco ativo de discussão dos direitos sociais, culturais e ambientais, reforçando toda e qualquer forma de luta por valores cidadãos, humanitários e socialmente defensáveis.

\section{Emergência em Museus}

O painel que marcou a Conferência de Milão, ao qual me refiro hoje, trouxe ainda um outro tema relevante - a emergência em museus - apresentado por Marlen Mouliou.

Segundo ela, os museus podem se tornar instrumentos que contribuam para acudir as emergências humanas e sociais. Com esse propósito, os museus devem desenvolver as competências de:

- Curar relações humanas.

- Reconhecer mudanças sociais.

- Estimular o público a discordar e a avaliar diferentes visões.

- Compartilhar experiências e conhecimentos.

- Ser espaço de compaixão e humanidade.

${ }^{6}$ Espaço público aberto, onde as pessoas se reuniam na Grécia Antiga para atividades políticas, sociais, comerciais ou culturais. 
Esperamos que o museu possa se revelar como algo indispensável, básico e necessário para a vida humana. Só assim ele manterá seu sentido maior e agregador.

Por tudo isso, e para finalizar, só nos resta uma certeza - a de que não podemos deixar de nos questionar continuamente, incessantemente:

- Museus para quê? E para quem?...

- O museu contemporâneo tem-se mostrado um elo de inovação e de transformação social?

E é nesse sentido mais amplo que devemos nos manter descontentes com qualquer resposta, para que a pergunta persista no ar, de forma a iluminar os museus, inspirando-os a se questionarem, inovarem e reinventarem.

\section{Obrigada!}

\section{Referências bibliográficas:}

GRENIER, Catherine. La Fin des Musées. Paris: Editions du Regard, 2013.

MACGREGOR, Neil. A History of the World in 100 Objects. London: Penguin Books, 2010.

FRANCO, Maria Ignez Mantovani. Conferência Internacional "Museus para quê?", promovida pelo British Council e Museu do Amanhã. Rio de Janeiro, nov. 2016 (apresentação oral).

FRANCO, Maria Ignez Mantovani. “A construção da imagem internacional do Brasil por meio da cultura. Do Gabinete de Curiosidades à cerimônia de abertura dos Jogos Olímpicos no Brasil." Revista ouvirOUver. Uberlândia: Universidade Federal de Uberlândia, v. 13 n. 2 pp. 348-360, jul.|dez. 2017. 